\title{
ANSWERING BACK TO PROSPERO: GEORGE LAMMING AND THE INSCRIPTION OF CALIBAN'S DIFFERENCE ${ }^{1}$
}

\author{
Sirlei Santos Dudalski
}

...But Caliban keeps answering back, and it is his refusal to be silent which now bullies Prospero into the crucial charge:..

GEORGE LAMMING, The Pleasures of Exile

And if the word "classic" has any meaning at all it must refer to a work which is able to mean again, and perhaps mean something else.

CHARLES MAROWITZ, Recycling

Shakespeare

...We are pro-Whitman and pro-Melville and pro-Mark Twain. We don't mind worshipping in that kind of cathedral; for there is a possibility-indeed, more than a possibility-that we will introduce some new psalms.

GeORge LAMming, The Pleasures of Exile

In the introduction to The Pleasures of Exile, George Lamming uses an indigenous Voodoo religious ritual called the Ceremony of the Souls to contextualize metaphorically what he calls his "way of seeing" his condition as a Caribbean writer living in self-imposed exile. The Ceremony of the Souls - also present in his novel Water with Berries (1971) — is a ritual of redemptive dialogue between the living and the dead. The relatives of the dead wait for him/her to appear through a priest, that is, to talk through this person. In this drama of communion the living and the dead discuss things never discussed before when the person was alive, "it is the duty of the Dead to return and offer, on this momentous night, a full and honest report on their past relations

\footnotetext{
${ }^{1}$ Paper presented at the IV Jornada de Estudos Shakespearianos. São Paulo, USP, October 24-26, 2012.
} 
DUDALSKI - Answering Back to Prospero...

with the living" (Lamming, 1995, p. 9). The purpose of the ceremony is to establish a contract between the deceased and his/her relatives in which past problems would be discussed and consequently resolved, so that the dead as well as his/her relatives could be free.

Through this rite Lamming creates a hypothetical trial in which a witness arrives and wants to assume Prospero's privilege of magic, that is, wants to inscribe him/herself as a producer of texts. This witness also sees himself as a direct descendant of Caliban and claims to be the key witness to the trial. In addition to being the most important witness, the narrator of The Pleasures of Exile considers himself also to be the prosecutor, the defence attorney and the judge and, according to him, there are no degrees of innocence since to be innocent is to be "eternally dead".

And this trial embraces only the living. Some may be corpses, but their evidence is the evidence of a corpse who has returned to make the unforgivable apology: 'Gentlemen I did not realise. Although I was there, although I took part, believe me, I did not realise! I was not aware!' The confession of unawareness is a confession of guilt. This corpse, dead as he may be, cannot be allowed to go free; for unawareness is the basic characteristic of the slave. Awareness is a minimum condition for attaining freedom. (Lamming, 1995, p. 12)

Writers like Lamming and others who appropriate a classical text from the perspective of the postcolonial racial and/or female other seem to be demanding a dialogue with the dead. In other words, they want to establish a communication with texts which were exclusively read through the viewpoint of a European male tradition. Their preoccupation is not to discard canonical texts, but to show how they can be used to convey different meanings. In order to achieve his goal the colonial writer may be involved in a process of negotiation with the texts from the Western tradition in which past issues which influence the present and the future of the colonised would be brought up similarly to what happens to the dead and his/her relatives in the Ceremony of the Souls.

There has been a tendency for colonial and postcolonial writers to identify themselves with Caliban, the one who has learned the master's language and can use it 
DUDALSKI - Answering Back to Prospero...

to curse him. Indeed, postcolonial writers use Caliban as an icon of their condition as Lamming does in The Pleasures of Exile, anticipating the discussion of postcolonial literature. As a writer Lamming reflects about his self-imposed exile in England, cultural hybridity and minority discourse. He uses Shakespeare's The Tempest to reveal his relation as an individual writer and a Caribbean to the coloniser's tradition. The writer shows himself as a self-conscious producer of alternative discourses and although his work has an autobiographical framework, it also has a socio-political scope, dealing with issues such as imperialism, colonialism, and the writing produced by the colonised.

As Lamming states, "modern Caliban is a greedy learner. He can learn methods of investigation as thoroughly as any Prospero with similar facilities" (1995, p. 159). The contemporary Caliban is aware of his relation to Prospero and he uses Prospero's tools to write himself, to write his own history without having to ask permission to his former master. Even having inherited a legacy of dispossession, the contemporary Calibans, or as Lamming uses sometimes, the descendants of Caliban, now belong to an age of negotiation of the relationship between past and present.

Lamming's own experience as a writer in England, where he has to negotiate his heritage provides a parallel to the relationship of the colonised and the cultural tradition of the coloniser. For instance, as Lamming puts it, when his Caliban arrives at Prospero's home, he sees many "thrones" and takes possession of one, but realising it is not the right size for him, he wants it to be changed. He would like to have a throne with a new shape. At first Europeans do not seem to agree with him since tradition has dictated that all thrones must be alike. After a lot of arguing, Caliban's first concession is granted: the shape of the throne can be changed. Yet Prospero does not want any change to happen. He would permit Caliban to sit in one of the existing thrones as long as he wanted but to change the shape of the throne would imply another change: Prospero's change. However, Prospero fears too many changes since he is afraid of losing the control he once had (Lamming, 1995, p. 83).

Throughout The Pleasures of Exile, Lamming uses the relationship between Prospero and Caliban to analyse the relation of a writer to the culture that colonised his 
DUDALSKI - Answering Back to Prospero...

history. Using The Tempest as a framework to his book he challenges Shakespeare's authority and announces he has got hold of Prospero's weapons, being also able to create his own discourse. Prospero has lost his privilege of ownership and it is high time changes were made and the European started to learn how to deal with this new condition: "The time is ripe — but may go rotten — when masters must learn to read the meaning contained in the signatures of their former slaves. There may be more murders; but Caliban is here to stay" (Lamming, 1995, p. 63).

After Lamming's seminal work dealing with The Tempest metaphor, the appearance of criticism and literary works following the same path has proved that actually Caliban is here to stay. Besides literary criticism dealing with colonialism and the question of alterity in The Tempest, there are literary texts which borrow the play's characters and plot to make the dead speak through different mouths. Writers have not asked permission; on the contrary, they feel at ease to appropriate the play and establish a dialogue in which questions based on issues of race and gender cannot go into hiding. Therefore the dialogue between the living and the dead seems to be unavoidable, expressing, thus, the awareness of the colonised concerning his/her condition of oppression. And, as Lamming argues, this awareness is a prerequisite for attaining freedom.

Shakespeare's The Tempest has inspired a variety of socio-political and creative works which show this dialogical concern. Recently some of the literary works generated from a dialogue between writers of colonised countries and canonised texts have been usually called "appropriations". These texts aim at subverting the authority of writings that were not used to being questioned in what concerns their political implications. In fact they are produced with the intent to bring to the fore issues which were either not sufficiently dealt with in the classic text, or utterly disregarded. For instance, issues such as race and gender are analysed from the point of view of the noncanonical writer, the "appropriator", taking into account the place from where he/she is speaking, that is, his/her own experience or/and the experience his/her people has undergone when or after facing a situation of oppression or colonisation. 
DUDALSKI - Answering Back to Prospero...

The idea of intertextuality is based on the assumption formulated by Julia Kristeva that "any text is constructed as a mosaic of quotations; any text is the absorption and transformation of another" (Moi, 1986, p. 37). She formulates the concept of intertextuality following Bakhtin's idea of dialogism, which implies that a text enters into dialogue not only with other written texts, but also with nondiscursive texts. The dialogical writing has a profound historical dimension. Bakhtin situates the text within history and society, which are then seen as texts read by the writer, and into which he inserts himself by rewriting them. As Clayton and Rothstein put it, "Bakhtin's writer is an agent, acting on and in relationship to the materials of history (which are always textual), and asserting a self as he 'inserts' his writing-agency into the textual trajectory of history" (1991, p. 324).

Although Kristeva uses Bakhtin's dialogism to elaborate her thesis on intertextuality, in her formulation she puts aside the author. The writer as an agent is not important to the study of the text; on the contrary, the author is dead, as announced by Roland Barthes (1977). He/she does not exist since what matters is only the relation of one text to others. This poststructuralistic assumption has emerged as a response to the previous notion of influence that presented an author-centred study of literary works. Although, as Susan Friedman claims (Clayton and Rothstein, 1991, p. 152), "Intertextuality was born of an anticolonialist resistance to the concept of hegemonic influence", Kristeva's formulation when erasing agency becomes improper to a use in which the agency of the writer occupies a special place such as in postcolonial literature.

Both influence and intertextuality have had their original implications enlarged in order to include a more democratic reading of texts. Feminist critics, for instance, have used influence to include a reading of female tradition, another tradition in which women influence women. ${ }^{2}$ Clayton and Rothstein point out that "for many kinds of political criticism, a broad version of influence probably works better than does

\footnotetext{
2 Ellen Moer'sLiterary Women ,1976; Elaine Showalter's A Literature of Their Own, 1977; Sandra Gilbert and Susan Gubar'sThe Madwoman in the Attic, 1979.
} 
DUDALSKI - Answering Back to Prospero...

intertextuality" (1991, p. 10). Yet Susan Friedman states that the feminist Nancy K. Miller defends a "political intertextuality" which refuses to accept the "anonymity that Barthes, Foucault, and Kristeva promote with their versions of intertextuality". "Political intertextuality", as defined by Miller, is to "place oneself at a deliberately oblique (or textual) angle" (1991, p. 158). By separating the concept of intertextuality from the death of the author, Miller returns to Bakhtin's original idea of dialogism which inserts the writer as "self" in a position of constant negotiation with other texts.

Neither influence nor intertextuality — unless it is a "political intertextuality" or the idea of con-texts as elaborated by Peter Hulme and Francis Barker (1985) - seem to be adequate terms to refer to the literary production of postcolonial writers who try to subvert the authority of canonised texts. The first term is linked to a dominating idea of source, originality and genius while the second one, as it is formulated by the poststructuralists, does not permit the writer to be inscribed as a person, as the subject of his own discourse. Furthermore, these terms usually bring to mind the discussion on theory made by a dominating "centre" in which works that represent a male white European tradition were/are praised without much questioning. It is true, however, that a discussion on theory will hardly be dealt with without taking into account what was discussed and produced before; furthermore, perhaps, it is not the case of replacing theories, but of being more aware of their political implications and of the necessity of utilising critically what we can.

The term "appropriation", instead of influence and intertextuality, seems to be more adequate to express the relationship between some texts originated in a colonial or postcolonial context since it does not seem to have been contaminated with previous Eurocentric concepts. Indeed, according to Affonso Romano de Sant'Anna (1988), this term was introduced in Literature quite recently through Art. By displaying ordinary objects in a context different from the usual, some artists provoked a kind of dislocation of the previous meaning of the object displayed, thus giving rise to a feeling of bewilderment. The important thing about this dislocation is not the process of appropriation itself, but the result and effect it provides. As Sant'Anna points out, when 
DUDALSKI - Answering Back to Prospero...

Salvador Dali paints a moustache in Leonardo da Vinci's Mona Lisa, he is appropriating a cultural sign in order to invert its meaning (p. 47).

Having Sant'Anna's example in mind, it is not surprising that the term appropriation started to be used to designate works produced by writers from colonised countries, which conveyed political issues concerning their experience of colonialism. The Oxford Dictionary's definition to appropriation is “to take and make one's own". It is interesting to notice that to appropriate is not to borrow; on the contrary, it seems to imply the idea of getting something from someone without even asking for permission. Appropriation can be seen as explicitly a "talking back" of non-canonical writers. It does not imply a destruction of the "father", since there might be no "father" or any "anxiety of influence" — as formulated by Harold Bloom (1991). The text appropriated should not be "eternally dead" — as Lamming explains about the Ceremony of the Souls - since it is not "innocent" and, as a consequence, it should say things which were not allowed to be said before. The writer who appropriates wants to give voice to what was silenced in the classic text for a long time.

In Women's Re-Visions of Shakespeare, Marianne Novy claims that the works discussed in the anthology cannot fit into the category of "influence studies" or "offshoots" since "the essays are not readings passively receiving Shakespeare or writings dutifully imitating him but enterprises of both creativity and criticism" (1990, p. 2). The word "Re-Vision" in the title of the book shows her choice of term, though it is important to notice that it is hyphened. As the reader can observe the female writers who respond to Shakespeare in the book are either English or North Americans. However, in Cross-Cultural Performances: Differences in Women's Re-Visions of Shakespeare, also edited by Novy, although "Re-Visions" is in the title again, the term "appropriation" is used more frequently throughout the book. It is interesting to point out that "appropriation" is more used to specify a context of colonialism rather than one oriented by gender issues. Furthermore the idea of place seems to be strongly emphasised with this term; some authors say Indian/ Canadian/ African/ Caribbean appropriations of Shakespeare. Perhaps it is so because of the idea of dislocation which 
DUDALSKI - Answering Back to Prospero...

the act of appropriation carries and which also implies the placement or displacement of a work to an alien culture.

Words such as "rereading", and "rewriting" sometimes replace the term "appropriation", although they seem to me not to be so emphatic because of the prefix "re-". This prefix here seems to reinforce the idea that something came before, that an action is repeated, continued, instead of being a real rupture. Jonathan Crew shares this same kind of preoccupation concerning the prefix:

For [Jonathan] Crew, the set of terms on which current criticism so frequently depends - rewriting, revision, representation, refiguring, reconstituting — carries an inherently problematic echo of the structure of the word Renaissance itself. These terms announce a break that is undercut by the inevitable indication built into the prefix "re-" of an insuperable connection with what came before. (Novy, 1993, p. 258)

Charles Marowitz seems to see no problem with the use of such words. On the contrary, he states, "Our job is to retrace, rediscover, reconsider and re-angle the classics — not simply regurgitate them. 'I re-think therefore I am', said Descartes — or at least he should have" (1991, p. 24). Although Marowitz's sentence is worth quoting, I still do prefer a term without the prefix "re-" since it may carry questionable concepts. Indeed, it should be pointed out that when hyphened, as in both Novy and Marowitz, these "re-" words tend to express some of their complexities.

As Marowitz himself states in his sentence used in one of the epigraphs to this article, a classic should be able to "mean again, and perhaps mean something else". My point is that the word "appropriation" is a better one to emphasise that the canonical text is used to "mean something else". Perhaps this may be so because appropriation, as Sant'Anna states, being a relative of parody is also used to invert the meaning of a work. According to him, dessacralization, a sort of disrespect for the work, and a critique of its ideological meaning are the main characteristics of appropriation (1988).

By using The Tempest both in The Pleasures of Exile and Water with Berries to present "a certain state of feeling which is the heritage of the exiled and colonial writer from the British Caribbean" (1995, p. 9), Lamming shows to be aware of his role as a 
DUDALSKI - Answering Back to Prospero...

consumer of English Literature and a producer of an alternative discourse. Indeed, in The Pleasures of Exile, he warns the reader that due to the way he makes use of the Shakespearean text he expects the charge of blasphemy, which according to him must be seen as a privilege of the excluded Caliban.

In The Tempest's context, "appropriation" may remind us of the usurpation which Caliban suffers in the play. In order to really answer back to Prospero in an autonomous way, Caliban may use a more emphatic, more effective or stronger word to express what some may consider his "blasphemy".

Due to the political tension The Tempest is able to arouse, the term "appropriation" sounds more interesting to the purpose of the present discussion. In addition, it is also relevant to point out that Caliban as an anagram to Cannibal, name given to the inhabitants of the Caribbean (Retamar, 1988, p. 17), suggests, in this context, the idea of literary anthropophagy. This idea was born during the Brazilian Modernist Movement with "O manifesto paubrasil" (The Brazilwood Manifesto) and "O manifesto antropófago" (The Cannibalist Manifesto). In his manifestos, Oswald de Andrade gives emphasis to the conflicting relationship among different cultures and to the point of view of the colonised who revolts and critically decides what will or will not be consciously assimilated to establish the "new". "The Cannibalist Manifesto" argues for the necessity of devouring the other, that is, the other's culture. The colonised incorporates the metaphor of the cannibal - the one who eats human flesh — but the "body" to be devoured in this context is literature. According to Oswald de Andrade, the assimilation of alien cultures should happen although foreign cultures should not be copied but digested, absorbed, and finally excreted when they are no longer useful; he is interested in appropriating what does not seem to belong to him: "Tupi, or not Tupi, that is the question" (Andrade, 1970, p. 13).

In "Tupi, or not Tupi, that is the question" Andrade critically uses what is perhaps Shakespeare's most quoted sentence to show how appropriation and assimilation can take place. Assimilation of the others' culture is a crucial point when the subject is colonialism. To the dominating, assimilation should happen since his 


\section{DUDALSKI - Answering Back to Prospero...}

culture is regarded as the best, whereas to the dominated it might mean acceptance of his/her condition of colonised. However, Caliban, like the anthropophagus, has not meant passive acceptance; indeed his critical assimilation has meant an appropriation which implies resistance to a dominating power. With his curse, Caliban criticises any kind of imposition and questions the concept of value applied to canonical texts as well. He takes the coloniser's text and uses it in a way the difference will be inscribed. Furthermore, by doing this and acting as an agent, Caliban announces his/her particularity and importance as such, dismantling the idea of ownership concerning the appropriated work, and, as a consequence, dismantling also the authority of the European text. The text does not belong only to Europeans, it is not exclusive. A new usage of the text is claimed.

You taught me language, and my profit on't

Is I know how to curse. The red plague rid you

For learning me your language.

W. Shakespeare, The Tempest, I.ii

The use of the word "appropriation" in the postcolonial discussion on language reinforces what has been discussed so far about its use applied to literary works. The "appropriation" of language, according to Ashcroft et al., is the process by which language is taken and made to "bear the burden" of the person's own cultural experience or, as Raja Rao puts it, it is "to convey in a language that is not one's own the spirit that is one's own" (Ashcroft et al., 1989, p. 39). The authors also emphasise that language, as well as writing, is considered a tool and is used in various ways to express widely differing cultural experiences.

It has been widely discussed that language works as a medium of power and that it comes with a whole concept of ideas and cultural experience forced on the colonised, who, like Caliban, have to give a new usage to the "gift of language", showing, as Lamming puts it, that Prospero is no more the only one to hold the privilege of "magic", that is, of writing. The language of the coloniser, which was used to control and manipulate the colonised, turns into a tool used with the purpose of decolonizing when 
DUDALSKI - Answering Back to Prospero...

appropriated by the pen of writers from former colonies. The language is used in a way which makes explicit the tension between different cultures. As AniaLoomba says, Caliban manages to curse not only because of Prospero's language but also because of his inheritance: even though Sycorax is absent, she shapes his curse (Novy, 1993, p. 230).

The encounter between different cultures in a colonising situation is shown mainly through the changes language undergoes. Indeed neither the coloniser nor the colonised will ever be able to be the same after their encounter. For instance, in order to "convey his/her own spirit" in a language that is not his/her own, the colonised has to make some adaptations. Thus, now English has to face a large number of "englishes" (Ascroft et al., 1989), which differ from the standard English, the language used by the coloniser. The appearance of "englishes" has provided new dimensions to literary production. Writers from countries which have been through a colonising process have developed the desire to show in their work the tension between the standard and the "different" language resulting from the cultural encounter. Not only will their plots and characters show the conflicting relationship between coloniser and colonised but also their language will make their intentions explicit. They appropriate the language that was used to oppress in order to establish a difference so they can inscribe their "curse" in a way which shows their unique cultural identity. The inscription of the colonised people's difference has been extremely important to postcolonial societies, as Ashcroft puts it:

The presence or absence of writing is possibly the most important element in the colonial situation. Writing does not merely introduce a communicative instrument, but also involves an entirely different and intrusive (invasive) orientation to knowledge and interpretation. In many post-colonial societies, it was not the English language which had the greatest effect, but writing itself (1989:82).

Caliban's acquisition of Prospero's language, metaphorically, goes beyond the spoken language. In Lamming's words, Caliban is a good learner. He not only learns to speak Prospero's language but also learns to write in it to write back to the empire. 
DUDALSKI - Answering Back to Prospero...

However, Caliban's writing does not reproduce the coloniser's writing since he managed to negotiate and get "a new throne", that is, his experience of colonised provides him with an understanding of both sides of the coin: he may curse or do whatever he wants since he is free now, the only imposition on him is awareness. And awareness is what the contemporary Caliban seems to have most. He knows that in order to be effective, to deconstruct, to unshape the image the colonised has built for him, he has to write. Writing, which was once used to colonise, imprison and annihilate Calibans, has turned out to be their ally.

The importance of writing receives so much emphasis that TzvetanTodorov (1988) attributes the Aztecs' defeat to the absence of literacy in Mexico. They mastered the communication with the world, that is, they could easily read natural signs, and the Aztec chief, Moctezoma, was a master of the spoken word, who could interpret the divine, the natural and social through clues and foreboding, but when he had to face the unexpected he failed. The Aztecs could not manage to communicate among themselves in the battle with the Spanish since their code reinforced repetition, not improvisation. Although the Spanish army was smaller, the Indians had no chance to win the battle due to their incapacity to master human communication - in other words, to manipulate information. Their oral tradition did not facilitate this kind of communication, whereas the European written tradition did. Following Todorov, Inga Clendinnen affirms that the strategic intelligence and semiotic sophistication which made Cortés and his men triumph are due to "a European cultural capacity grounded in 'literacy', where writing is considered "not as a tool, but as an index of the evolution of mental structures"" (Greenblatt, 1993, p. 13).

Writing was also central to the eighteenth century debate over slavery. After Descartes, reason was considered to be the most important human characteristic, and writing taken to be a visible sign of reason. But, at that time blacks were not permitted to read or write; literacy was a violation of a law:

Hegel, echoing Hume and Kant, claimed that Africans had no history, because they had 


\section{DUDALSKI - Answering Back to Prospero...}

developed no systems of writing and had not mastered the art of writing in European language. ... Without writing, no repeatable sign of the workings of reason, of mind, could exist. Without memory or mind, no history could exist. Without history, no humanity, as defined consistently from Vico to Hegel, could exist. (Gates, 1986, p. 11)

It is extremely important to highlight the relation among writing, memory and history. Writing for the blacks in the nineteen century in the United States was a question of defending their right to be included and not excluded from what was called "humanity", since their valuable oral tradition did not count to Europeans. And according to ethnocentric ideas, Africans did not have the ability to write. As Henry Gates states in "Race", Writing and Difference, the Anglo-African writing appeared as a response to allegations of its absence. Writing provided the Africans with a “certificate of humanity" (1986:13).

Writing, which once was used to exclude the Africans, and other non-Europeans, becomes a means of struggle, of denouncing the forgery of a race. Control over language is considered one of the principal features of imperial oppression. When discussing postcolonial writing, The Empire Writes Back also presents a discussion "of the process by which the language, with its power, and the writing, with its signification of authority, has been wrested from the dominant European culture" (Ashcroft et al., 1989, p. 7). Postcolonial discussion has been based on the question of writing made by the "margins", that is, by peoples who suffered the experience of colonisation and whose literature was considered "inferior" in relation to a "centre" (ibidem).

As I conclude I shall make clear my intent to emphasise George Lamming's ideological position in his use of The Tempest. As it has been discussed so far, the idea of appropriation highlights the inscription of an author as an agent and representative of a group and a culture. The kind of relationship the author - in this case Lamming develops with the Shakespearean play and the characters' metaphor is determined by his experience as a minority writing in a language which was used to be exclusively the oppressor's.

The relationship between The Tempest and its appropriations echoes the tension 


\section{DUDALSKI - Answering Back to Prospero...}

created by various readings of race and gender. As in the Ceremony of the Souls mentioned in the beginning of this text, the dead, in this context metaphorically The Tempest (its plot and characters), will have to return in order to attempt to establish a more democratic "way of seeing" the racial and female other. This "way of seeing" is explicitly different from the past when texts were linked to the idea of influence and evaluated by European standards which considered the works produced by the colony a reflection/imitation of the literature of the coloniser. For instance, North American Literature was accepted as nothing more than an offshoot of the "parent tree" - British Literature. This metaphor of the "parent tree" was used intentionally to stress age, experience, tradition, and above all, to confer more value to the literature of the coloniser (Ashcroft et al., 1989, p. 16).

As I have pointed out, as Eurocentric concepts, influence and, to a certain extent, intertextuality, do not seem to serve to the special purpose of dismantling the hegemony of a traditional text. Yet Lamming's negotiation of the past, his metaphorical use of the Haitian Ceremony of the Souls and the trial he calls on in The Pleasures of Exile seem to be closer to Bakhtin's dialogism, or to Miller's political intertextuality or even to the Brazilian Literary Anthropophagy. What seems to approximate these theories is the critical position the second text takes in relation to the canonised one. The critical dialogue Lamming establishes with the Shakespearean work reveals ways in which Caliban might inscribe his difference and answer back to Prospero in a clear and loud tone.

\section{References}

ANDRADE, Oswald de. Do pau-Brasil à antropofagia e às utopias. Rio de Janeiro: Civilização Brasileira, 1970.

ASHCROFT, Bill et al. The Empire Writes Back. London: Routledge, 1989.

BARKER, Francis; HULME, Peter. Nymphs and Reapers Heavily Vanish: The Discursive Con-texts of The Tempest. In: DRAKAKIS, John (Ed.). Alternative 


$$
\text { DUDALSKI - Answering Back to Prospero... }
$$

Shakespeares. London: Methuen, 1985. p. 191-205.

BARTHES, Roland: The Death of the Author. In: Image, Music, Text. Selected and translated by Stephen Heath. London: Fontana, 1977.

BLOOM, Harold. A angústia da influência: uma teoria da poesia. Trad. Arthur Nestrovski. Rio de Janeiro: Imago, 1991.

CLAYTON, Jay; ROTHSTEIN, Eric. Influence and Intertextuality in Literary History. Wisconsin: The University of Wisconsin Press, 1991.

ELIOT, Thomas Sterns. Tradition and the Individual Talent. In: Selected Essays. London: Faber and Faber, 1951, p. 13 -34.

GATES, Henry Louis Jr. (Ed.) "Race”, Writing and Difference. Chicago: University of Chicago Press, 1986.

GREENBlatT, Stephen (Ed.) New World Encounters: A Representations Book. Berkeley: The University of California Press, 1993.

LAMMING, George. The Pleasures of Exile. 1960. London: Allison \& Busby Ltd., 1995.

LAMMING, George.Water with Berries. New York: Longman, 1971.

MAROWITZ, Charles. Recycling Shakespeare. (The Applause Acting Series). New York: Applause, 1991.

MOI, Toril (Ed.). The Kristeva Reader. Oxford, Oxford Univ. Press, 1986.

NOVY, Marianne. Cross-Cultural Performances: Differences in Women's ReVisions of Shakespeare. Chicago: University of Illinois Press, 1993.

Women's Re-Visions of Shakespeare: On Responses of Dickinson, Woolf, Rich, H.D., George Eliot, and Others.Chicago: University of Illinois Press, 1990.

RETAMAR, Roberto Fernández. Caliban e outros ensaios. Trad. Maria Elena Matte e Emir Sader. São Paulo: Busca Vida, 1988.

SANT'ANNA, Affonso Romano de. Paródia, Paráfrase \& Cia.São Paulo:Ática, 1988.

SHAKESPEARE, William. The Tempest. The Arden Shakespeare.London: Routledge, 1994. 
DUDALSKI - Answering Back to Prospero...

TODOROV, Tzetan. A conquista da América: A questão do outro. Trad. Beatriz Perone. São Paulo: Martins Fontes, 1983.

WORTON, Michael, STILL, Judith (Eds.). Intertextuality: Theories and Practices. New York: Manchester Univ. Press, 1990. 